\title{
DAMPAK PENERAPAN KEBIJAKAN BEA KELUAR TERHADAP EKSPOR KAKAO INDONESIA
}

\section{Bryan Habib Gautama}

Kantor Pelayanan Utama Bea Cukai Tipe A Tanjung Priok, Pelabuhan Tanjung Priok, Jakarta Utara, 14210

E-mail: bryan.habib@customs.go.id

\section{INFORMASI ARTIKEL}

Tanggal masuk

[25-04-2019]

Revisi

[13-05-2019]

Tanggal terima

[14-05-2019]

\section{ABSTRACT}

The purpose of this research is to analyze the impact of export duty policy on Indonesian cocoa exports with several factors that influence cocoa exports, namely the amount of cocoa production, world cocoa prices, and the exchange rate of rupiah. This research uses Ordinary Least Square (OLS) analysis. To see the effect of the independent variables on the dependent variable, the researcher conducted a classic assumption before doing the test. Based on the results of the research obtained it can be seen that simultaneously the amount of cocoa production, world cocoa prices, the exchange rate of the rupiah, and the export duty policy have a significant effect on Indonesian cocoa exports. Partially, the amount of cocoa production and export duty policy has a significant positive effect on Indonesian cocoa exports. While the variable of world cocoa prices and the exchange rate of the rupiah did not significantly affect Indonesian cocoa exports. The research variable includes $73.98 \%$ of all causes that affect Indonesian cocoa exports, while other causes are not discussed in this study.

Keywords: export duty policy, cacao export, downstream industry development

\begin{abstract}
ABSTRAK
Penelitian ini bertujuan untuk menganalisis dampak kebijakan bea keluar terhadap ekspor kakao Indonesia dengan beberapa faktor yang mempengaruhi ekspor kakao, yakni jumlah produksi kakao, harga kakao dunia, dan nilai tukar rupiah. Penelitian ini menggunakan analisis Ordinary Least Square (OLS). Untuk melihat pengaruh variabel independen terhadap variabel dependen, peneliti melakukan uji asumsi regresi klasik terlebih dahulu sebelum melakukan pengujian. Berdasarkan hasil penelitian yang diperoleh dapat diketahui bahwa secara simultan jumlah produksi kakao, harga kakao dunia, nilai tukar rupiah, dan kebijakan bea keluar berpengaruh signifikan terhadap ekspor kakao Indonesia. Secara parsial, jumlah produksi kakao dan kebijakan bea keluar berpengaruh signifikan positif terhadap ekspor kakao Indonesia. Sedangkan variabel harga kakao dunia dan nilai tukar rupiah tidak berpengaruh signifikan terhadap ekspor kakao Indonesia. Variabel penelitian ini mencakup $73,98 \%$ dari seluruh sebab yang mempengaruhi ekspor kakao Indonesia, sedangkan sebab lainnya tidak dibahas dalam penelitian ini.
\end{abstract}

Kata Kunci: kebijakan bea keluar, ekspor kakao, perkembangan indsutri hilir 


\section{PENDAHULUAN}

Kakao merupakan salah satu komoditas utama ekspor Indonesia. Kakao memiliki peran yang penting dalam perekonomian nasional. Sebagai salah satu komoditi utama ekspor, kakao telah menuyumbangkan devisa negara yang besar. Kehadiran kakao juga memberikan dampak terhadap ketersediaan lapangan kerja serta pengembangan wilayah di beberapa sentra penghasil kakao, seperti Sulawesi Selatan, Sulawesi Tengah, Sulawesi Barat, dan Sulawesi Tenggara.

Menurut Kementerian Perindustrian, Perkebunan kakao di Indonesia mengalami perkembangan pesat dalam kurun waktu 20 tahun terakhir dan pada tahun 2002 area perkebunan kakao Indonesia tercatat seluas 914.051 ha. Perkebunan kakao tersebut sebagian besar $(87,4 \%)$ dikelola oleh rakyat dan selebihnya $6,0 \%$ dikelola perkebunan besar negara serta $6,7 \%$ perkebunan besar swasta.

Kualitas kakao Indonesia tidak kalah dengan hasil kakao dunia. Menurut Pusat Data dan Informasi Kementerian Perindustrian (2007), Kakao Indonesia bila dilakukan fermentasi dengan baik dapat mencapai cita rasa setara dengan kakao yang berasal dari Ghana dan kakao Indonesia mempunyai kelebihan yaitu tidak mudah meleleh sehingga cocok bila dipakai untuk blending. Keunggulan tersebut memberikan peluang yang besar bagi industri kakao di Indonesia.

Pada tahun 2017, International Cocoa Organization (ICCO) menunjukan produksi kakao di dunia didominasi oleh negara-negara benua Afrika seperti Pantai Gading, Ghana dan Nigeria dengan total produksi mencapai $76,5 \%$ dari produksi kakao seluruh dunia. Negara-negara Amerika Latin menjadi peringkat kedua dengan total produksi sekitar $16 \%$ dan negara-negara di Asia dan Oseania menjadi yang terendah dengan total produksi sekitar $7,5 \%$ dari keseluruhan produksi dunia.

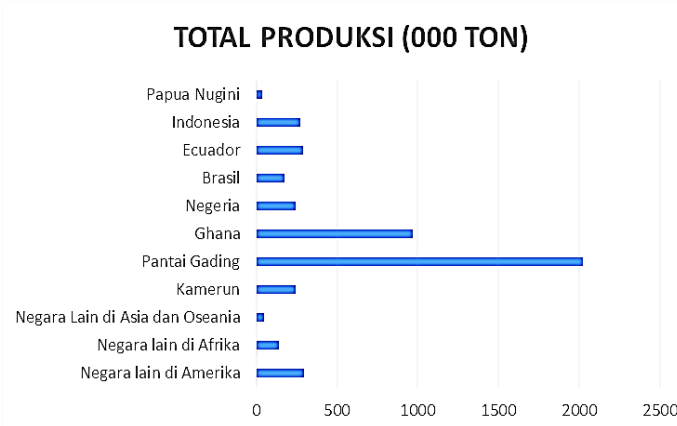

Gambar 1. Produksi Kakao Dunia

Berdasarkan Negara

Gambar 1 menunjukkan produksi kakao dunia dari negara penghasil utama. Produksi kakao dunia pada tahun 206/2017 mencapai 4.740.000 ton. Pantai Gading menjadi produsen terbesar dengan 2.020.000 ton. Ghana menjadi negara kedua dengan produksi kakao teringgi yaitu sebesar 970.000 ton. Ekuador merupakan negara di benua Amerika dengan produksi kakao terbesar sekaligus menjadi ketiga di dunia dengan total produksi 290.000 ton. Sedangkan Indonesia menjadi peringkat yang keempat dengan 270.000 ton diatas kamerun, Nigeria dan Papua Nugini.

Ekspor kakao terdiri atas beberapa barang yang diklasifikasikan berdasarkan Harmonized System ${ }^{l}$. Terdapat $20 \mathrm{HS}$ utama dari komoditi ekspor Indonesia (Badan Pusat Statistik, 2018). Sampai dengan 2010 komoditi kakao yang diekspor masih ditopang oleh ekspor biji kakao. Biji kakao merupakan bahan baku utama dari produk-produk seperti coklat, susu, dan lainnya.

Ekspor biji kakao yang belum diolah merupakan hal yang tidak menguntungkan bagi Indonesia. Biji kakao merupakan barang mentah yang belum diolah sehingga tidak terdapat nilai tambah pada

${ }^{1}$ Menggunakan BKTI 2012 
saat diekspor. Menyikapi hal tersebut, pemerintah mengeluarkan kebijakan Peraturan Menteri Keuangan No.67/PMK.011/2010 Penetapan Barang Ekspor yang dikenakan Bea Keluar dan Tarif Bea Keluar. Pengenaan bea keluar ekspor bagi biji kakao yang belum diolah ini bertujuan untuk mendukung tersedianya pasokan biji kakao bagi industri dalam negeri dan mempercepat program hilirisasi sektor pengolahan kakao di Indonesia. Akibat dari kebijakan tersebut nilai ekspor kakao menurun tajam dari 1.190.740 ribu dolar Amerika pada tahun 2010 menjadi 614.496 ribu dolar Amerika Serikat. Tren ekspor dari tahun 2009 hingga 2013 menunjukkan penurunan sebesar 25,3 persen (Hasrianti et al, 2014).

Kebijakan bea keluar memiliki tujuan untuk mengurangi ekspor Biji kakao dan mengubah skema ekspor dari barang mentah menjadi barang olahan. Permintaan terhadap kakao yang semakin besar setiap tahunnya menyebabkan biji kakao terus dieksploitasi untuk kepentingan ekspor. Akibatnya, industri dalam negeri kekurangan pasokan kakao dan mengharuskan impor kakao dari pasar internasional.

Kebijakan pemerintah tentang bea keluar menimbulkan gejolak pada pasar biji kakao. Terlebih penetapan tarif dan harga perkiraan ekspor dilakukan secara terus menerus menyebabkan perubahan dalam mekanisme pasar. Hal ini juga didukung oleh Salvatore (1997), yang menyatakan bahwa dengan adanya kebijakan maka akan menimbulkan perubahan harga di pasar domestik maupun di pasar internasional.

Penelitian ini dimaksudkan untuk menganalisis dampak bea keluar terhadap ekspor kakao Indonesia. Selain itu juga melihat dampak variabel-variabel lainnya yang diduga mempengaruhi ekspor kakao Indonesia di pasar internasional. Penelitian ini juga akan menganalisis keterkaitan kebijakan bea keluar terhadap hilirisasi kakao di Indonesia.

\section{KAJIAN LITERATUR}

\subsection{Kebijakan Bea Keluar}

Bea keluar adalah kebijakan pungutan terhadap komoditi tertentu yang hendak diekspor. Berdasarkan Undang-undang Kepabeanan No. 17 Tahun 2006 j.o. Undang-undang No. 10 Tahun 2010, Bea keluar dikenakan terhadap barang ekspor dengan tujuan untuk: 1) menjamin terpenuhinya kebutuhan dalam negeri; 2) melindungi kelestarian sumber daya alam; 3) mengantisipasi kenaikan harga yang cukup drastis dari komoditi ekspor tertentu di pasaran internasional; atau 4) menjaga stabilitas harga komoditi tertentu di dalam negeri.

Kebijakan bea keluar sudah dimulai sejak 1974 yang lebih dikenal dengan pajak ekspor, namun mulai menjadi perhatian dalam perdagangan CPO pada tahun 1994 sebagaimana tertuang dalam Keputusan Menteri Keuangan (KMK) Nomor 439/KMK.017/1994 (Syadullah, 2014). Komoditi pertama yang mendapatkan pengenaan bea keluar adalah CPO dan turunannya. Seiring berjalannya waktu, komoditi yang terkena bea keluar sampai saat ini berjumlah 5 komoditi yakni, CPO dan turunannya, biji kakao, produk hasil pengolahan mineral logam, kulit, dan kayu.

Pada tahun 2010, berdasarkan Peraturan Menteri Keuangan No. 67/PMK.011/2010 tentang Penetapan Barang Ekspor yang dikenakan Bea Keluar dan Tarif Bea Keluar terhadap biji kakao dikenakan bea keluar. Sampai dengan perubahan terakhir terhadap barang ekspor yang dikenakan bea keluar pada Peraturan Menteri Keuangan No. 13/PMK.010/2017, biji kakao dikenakan tarif yang besarannya dari 0\%-15\% 
berdasarkan harga referensi ${ }^{2}$. Untuk harga referensi sampai dengan USD 2000 tarif bea keluar untuk biji kakao adalah $0 \%$. Harga referensi USD 2000 sampai dengan USD 2750, biji kakao dikenakan tarif 5\%. Terhadap biji kakao yang memiliki harga referensi USD 2750 sampai dengan USD 3500 dikenakan tarif sebesar $10 \%$. Sedangkan untuk harga referensi melebihi USD 3500 dikenakan tarif sebesar $15 \%$.

Perhitungan bea keluar dibagi menjadi dua acara yaitu secara advalorum (presentasi) dan secara spesifik. Untuk komoditi biji kakao perhitungan bea keluar menggunakan cara advalorum (spesifik). Bea keluar dihitung berdasarkan rumus:

BK = Tarif $\mathrm{x}$ Jumlah Satuan $\mathrm{x}$ Harga Perkiraan Ekspor ${ }^{3}$ x Nilai Tukar Rupiah.

Pengenaan kebijakan bea keluar terhadap komoditi tertentu memberikan dampak terhadap harga komoditi tersebut. Menurut Mankiw (2003), kebijakan perdagangan merupakan kebijakan yang dirancang untuk mempengaruhi secara langsung jumlah barang dan jasa yang diekspor atau diimpor. Biasanya kebijakan perdagangan berbentuk melindungi industri domestik dari pesaing asing, baik dengan menerapkan pajak impor (tarif) atau membatasi jumlah barang dan jasa yang diimpor (kuota).

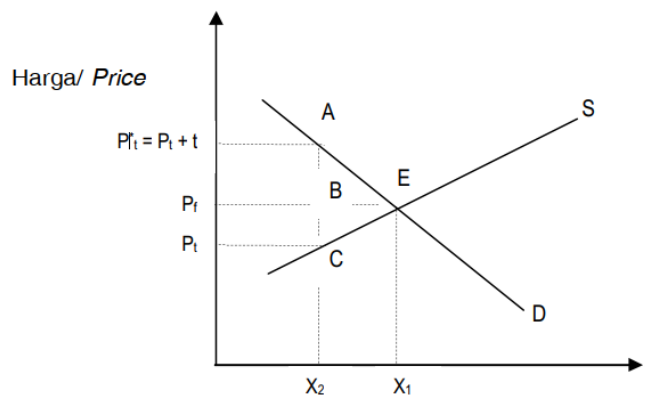

Jumlah Ekspor / Quantity of Exports

Gambar 2. Pembebanan Bea Keluar

${ }^{2}$ Harga rata-rata internasional yang ditetapkan oleh Menteri Perdagangan
Menurut Helpman dan Krugman (1989), bea keluar (pajak ekspor) akan mengurangi harga domestik, sementara itu harga ekspor akan meningkat.

Luhur dan Tajerin (2016) melalui persamaan Helpman dan Krugman menjelaskan Gambar 2., menggambarkan efek bea keluar sebesar t. Harga domestik akan turun menjadi $\mathrm{P}_{\mathrm{t}}$, mengurangi surplus produsen oleh area $\mathrm{P}_{\mathrm{f}} \mathrm{ECP}_{\mathrm{t}}$. Bagaimanapun, pendapatan hasil pajak sepadan dengan volume setelah pajak dikalikan dengan tarif pajak atau area $\mathrm{P}^{*} \mathrm{ACP}_{\mathrm{t}}$. hilangnya pajak sama dengan area BEC, sementara itu keuntungan perdagangan sepadan dengan area $\mathrm{P}^{*}{ }_{\mathrm{t}} \mathrm{ABP}_{\mathrm{f}}$

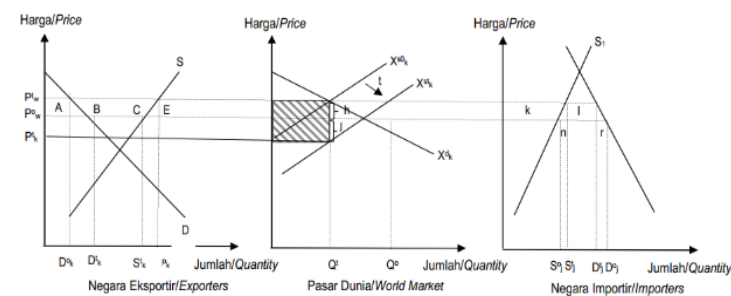

Gambar 3. Implikasi dari Kebijakan Bea Keluar

Menurut Munadi (2007), bea keluar mengimplikasikan kondisi yang lebih condong untuk membela kepentingan konsumen dalam negeri negara pengekspor dan produsen dinnegara pengimpor. Luhur dan Tajerin (2016) menjelaskan grafik Munadi, bahwa pajak ekspor dikenakan dalam bentuk pajak advalorum (t). Dengan adanya pajak, harga dalam negeri di negara pengekspor sebesar $P_{k}^{t}$, sementara harga dalam negeri di negara pengimpor adalah sebesar $P_{w}^{t}$ dengan jumlah ekspor yang disuplai sebesar $q_{t}$. Produksi dalam negeri di negara pengimpor j meningkat dari $O S_{j}^{O}$ menjadi $O S_{j}^{t}$. Produsen dalam negeri di negara pengekspor $\mathrm{k}$ dan konsumen di negara pengimpor $\mathrm{j}$ merupakan pihak yang

\footnotetext{
${ }^{3}$ Harga Patokan ekspor komoditi yang ditetapkan oleh Menteri
} 
dirugikan. Produksi di negara pengekspor akan menyusut dari $O S_{k}^{o}$ menjadi $O S_{j}^{t}$, sementara konsumsi di negara pengimpor j turun dari $O D_{j}^{o}$ menjadi $O D_{j}^{t}$. Ekspor turun dari $D_{k}^{o} S_{k}^{o}$ menjadi $S_{k}^{t} D_{k}^{t}$. Impor turun dari $S_{j}^{o} D_{j}^{o}$ menjadi $S_{j}^{t} D_{j}^{t}$.

\subsection{Penelitian Sebelumnya}

Penelitian tentang dampak kebijakan bea keluar terhadap ekspor kakao dilakukan oleh Makmun Syadullah (2012). Hasil penelitian menunjukkan penerapan kebijakan bea keluar menurunkan ekspor kakao Indonesia. Penerapan bea keluar terhadap ekspor belum mampu mendorong industri pengolahan kakao untuk beroperasi secara penuh.

Putri et al (2014), melakukan penelitian tentang pengaruh kebijakan pajak ekspor terhadap variabel-variabel perdagangan biji kakao Indonesia. Hasil penelitian menunjukkan pajak ekspor memiliki pengaruh terhadap volume ekspor, ketersediaan domestic, dan harga domestic. Pajak ekspor menekan volume ekspor dan meningkatkan ketersediaan dalam negeri.

Harsanti et al (2014) meneliti tentang dampak bea keluar kakao Indonesia terhadap country market power dan terms of trade. Penelitian ini menggunakan analisis Two Stage Least Square (2SLS) dan analisis terms of trade melalui indeks harga internasional dan indeks harga konsumen. Hasil penelitian menunjukkan pengenaan bea keluar hanya mempengaruhi market power dari Pantai Gading dan Ghana.

Penelitian Maulana dan Fitri (2017) tentang analisis ekspor kakao olahan Indonesia ke Sembilan negara tujuan tahun 2000-2014. Hasil penelitian menunjukkan variabel bea keluar biji kakao memiliki pengaruh positif dan signifikan terhadap volume ekspor kakao. Penerapan bea keluar menghambat ekspor biji kakao. Biji kakao yang tidak diekspor kemudian diolah sehingga meningkatkan nilai tambah di pasar internasional.

Suryana et al (2014) dalam penelitian tentang analisis perdagangan kakao Indonesia di pasar internasional menunjukkan hasil, variabel GDP riil per kapita negara tujuan, nilai tukar, dan bea keluar berpengaruh signifikan terhadap ekspor biji kakao Indonesia. Penelitian ini menggunakan analisis gravity model dengan pendekatan flow export model (FEM).

\section{METODE PENELITIAN}

Jenis penelitian yang digunakan adalah penelitian deskriptif. Penelitian deskriptif adalah penelitian yang dilakukan untuk mengetahui nilai masingmasing variabel, baik satu variabel atau lebih sifatnya independent tanpa membuat hubungan maupun perbandingan dengan variabel yang lain (Sujarweni, 2015). Penelitian ini menggunakan analisis kuantitatif.

Data yang digunakan dalam penelitian ini merupakan data sekunder berasal dari berbagai sumber. Data yang digunakan adalah data kuantitatif. Data kuantitatif adalah data yang dapat dinyatakan dalam bentuk angka (J. Supranto, 2008). Data yang digunakan dari tahun 2001-2017 berbentuk time series. Data nilai ekspor kakao Indonesia dan jumlah produksi kakao diperoleh dari publikasi dan website Badan Pusat Statistik (BPS). Harga kakao secara internasional diperoleh di The International Cocoa Organization (ICCO). Sedangkan, nilai tukar rupiah terhadap dollar Amerika (USD) diperoleh di website Bank Indonesia. Sampel yang digunakan adalah sampling jenuh. Sampling Jenuh adalah teknik penentuan sampel bila semua anggota populasi digunakan sebagai sampel (Sugiyono, 2011). 


\subsection{Terminologi Penelitian}

Teknik analisis data penelitian ini adalah analisis regresi Ordinary Least Squares (OLS). Model Ordinary Least Square (OLS) diperkenalkan pertama kali oleh seorang ahli matematika dari Jerman, yaitu Carl Friedrich Gauss, metode OLS adalah metode untuk mengestimasi suatu garis regresi dengan jalan meminimalkan jumlah kuadrat kesalahan dari setiap observasi terhadap garis tersebut (Kuncoro, 2003). Analisis regresi digunakan untuk melihat pengaruh dari variabel independen dan variabel dependen, sehingga diperlukan uji asumsi regresi klasik untuk melihat kelayakan data sampel untuk dijadikan sebagai objek penelitian.

Tahapan pertama dari penelitian ini adalah menentukan model persamaan yang digunakan. Persamaan yang digunakan pada penelitian ini mengambil bentuk sebagai berikut:

$\ln \mathrm{V}^{\mathrm{ex}}=\mathrm{a}_{0}+\mathrm{a}_{1} \ln \mathrm{JPCCO}+\mathrm{a}_{2} \ln \mathrm{P}^{\mathrm{ex}}+$ $\mathrm{a}_{3} \ln$ Exrate $+\mathrm{a}_{4}$ Dummy_BK $+\mathrm{e}_{1}$

\begin{tabular}{|c|c|}
\hline $\mathrm{V}^{\mathrm{ex}}$ & $\begin{array}{l}=\quad \text { Ekspor kakao } \\
\text { (USD). }\end{array}$ \\
\hline JPCCO & $\begin{array}{l}=\quad \text { Jumlah produksi } \\
\text { kakao Indonesia (ton). }\end{array}$ \\
\hline$P^{e x}$ & $\begin{array}{l}=\text { Harga kakao dunia } \\
\text { (US\$/ton). }\end{array}$ \\
\hline Exrate & $\begin{array}{l}=\text { Nilai tukar Rupiah } \\
\text { terhadap Dollar Amerika } \\
\text { (Rp/USD). }\end{array}$ \\
\hline Dummy_BK & $\begin{array}{l}=\quad \text { Dummy yang } \\
\text { menyatakan tahun } \\
\text { diberlakukannya bea } \\
\text { keluar terhadap kakao } \\
\text { tanpa diolah pada tahun ke- } \\
\text { t. D bernilai } 0 \text { untuk tahun } \\
\text { sebelum } 2010 \text { dan bernilai } \\
1 \text { untuk tahun } 2010 \text { dan } \\
\text { setelahnya. } \\
=\text { error term. }\end{array}$ \\
\hline
\end{tabular}

Persamaan dalam penelitian ini menggunakan transformasi data Logaritma Natural $(l n)$. Transformasi Logaritma digunakan untuk menghindari data dari pengaruh faktor lain yang menyebabkan data tidak memenuhi asumsi pengaruh aditif. Transformasi dilakukan menggunakan nilai $\mathrm{e}=2,71828$, mengikuti persamaan:

$$
y=\ln y^{\prime}=\log _{\mathrm{e}} y^{\prime} \ldots e^{y}=y^{\prime}
$$

Sebelum melakukan pengujian model persamaan dilakukan uji asumsi regresi klasik untuk mengetahui adanya gejala atau faktor pengganggu dalam model persamaan. Uji asumsi yang digunakan adalah uji Augmented Dicky Fuller, uji Jarque-Bera, uji Breusch-Godfrey Serial Correlation LM, uji VIF Multikoliniearitas dan uji Glejser. Pengujian dilakukan dengan bantuan program Eviews 9.0.

Tahapan ketiga adalah analisis regresi OLS. Analisis regresi dilakukan untuk mengukur hubungan antara dua variabel atau lebih, juga menunjukkan arah hubungan antara variabel dependen dengan variabel independen (Ghozali, 2011). Untuk mengukur kemampuan model statistika dalam menerangkan variasi digunakan koefisien determinasi $\left(\mathrm{R}^{2}\right)$. Nilai yang mendekati satu berarti variabel-variabel independen memberikan hampir keseluruhan informasi yang dibutuhkan untuk memprediksi variasi variabel dependen. Pengujian hipotesis secara simultan adalah menguji apakah variabel independen secara bersama-sama dengan variabel dependen dan pengujian parsial yaitu untuk menguji variabel independen terhadap variabel dependen satu per satu.

\subsection{Uji Stasioneritas}

Dalam model-model ekonometrika dengan data time series mengharuskan data atau variabel yang digunakan 
stasioner. Sekumpulan data dinyatakan stasioner jika nilai rata-rata dan varian dari data time series tersebut tidak mengalami perubahan secara sistematik sepanjang waktu, atau sebagian ahli menyatakan rata-rata dan variannya konstan (Djalal dan Hardius, 2006). Untuk memastikan data yang digunakan tidak mengandung root atau data harus stasioner dilakukan uji Augmented Dickey-Fuller (ADF). Uji ini dilakukan dengan "menambah" tiga persamaan sebelumnya dengan menambahkan nilai lag dari variabel dependen $\Delta \mathrm{Y}_{\mathrm{t}}$ (Gujarati, 2004). Formulasi uji ADF sebagai berikut: $e \mathrm{t}$

$$
\Delta \mathrm{Y}_{\mathrm{t}}=\beta_{1}+\beta_{2} \mathrm{t}+\delta \mathrm{Y}_{\mathrm{t}-1}+\sum_{i=1}^{m} \alpha_{\mathrm{I}} \Delta \mathrm{Y}_{\mathrm{t}-\mathrm{I}}+
$$

Berdasarkan model tersebut kita dapat memilih tiga model yang akan digunakan untuk melakukan Uji ADF yaitu, model tanpa intersep, model dengan intersep, dan model dengan intersep dan variabel bebas waktu.

\subsection{Uji Normalitas}

Uji normalitas dilakukan untuk mengetahui data yang digunakan berdistribusi normal atau tidak. Uji normalitas dimaksudkan untuk menguji nilai residual yang telah distandarisasi pada model regresi berdistribusi normal atau tidak (Suliyanto, 2011). Dalam model regresi linier, asumsi ditunjukkan oleh residual yang berdistribusi normal. Model regresi dinyatakan baik apabila model regresi yang dimiliki berdistribusi normal atau mendekati normal, sehingga layak dilakukan pengujian secara statistik. Pengujian normalitas data variabel menggunakan Test Jarque-Bera.

Data berdistribusi normal atau tidak ditunjukkan secara sederhana dengan membandingkan nilai Probabilitas JarqueBera hitung dengan tingkat signifikansi alpha 0,05 (5\%). Apabila Prob. JarqueBera hitung lebih besar dari 0,05 maka dapat disimpulkan bahwa residual berdistribusi normal dan sebaliknya, apabila nilainya lebih kecil maka tidak cukup bukti untuk menyatakan bahwa residual berdistribusi normal.

\subsection{Uji Autokorelasi}

Menurut Ghozali (2012), uji autokorelasi bertujuan untuk menguji apakah dalam model regresi ada korelasi antara kesalahan pengganggu pada periode-t dengan kesalahan pengganggu pada periode $\mathrm{t}-1$ (tahun sebelumnya). Untuk membuktikan tidak adanya autokorelasi dapat dilakukan dengan 2 model pengujian yaitu, dengan uji DurbinWatson, dan Uji Breusch-Godfrey Serial Correlation LM Test.

Penelitian ini menggunakan Uji Breusch-Godfrey Serial Correlation LM Test. Interpretasi hasil pengujian dinilai dari Probabilitas F hitung dan tingkat signifikansi alpha pada 5\%. Gejala autokorelasi terjadi apabila nilai Probabilitas F hitung lebih kecil dari nilai alpha 0.05 , begitu pula sebaliknya.

\subsection{Uji Multikolinieritas}

Uji multikolinieritas bertujuan untuk menguji model regresi ditemukan adanya korelasi di antara variabel independen. Jika variabel bebas saling berkorelasi, maka variabel-variabel ini tidak ortogonal. Variabel ortogonal adalah variabel bebas yang nilai korelasi antar sesama variabel bebas sama dengan nol.

Model regresi yang baik seharusnya tidak terjadi korelasi antara variabel independen. Jika terbukti ada multikolinieritas, sebaiknya salah satu independen yang ada dikeluarkan dari model, lalu pembuatan model regresi diulang kembali (Singgih Santoso, 2010:234)

Pengujian multikolinearitas dilihat dari besaran VIF (Variance Inflation Factor) dan Tolerance. Untuk menguji multikolinieritas dengan cara melihat nilai 
VIF masing-masing variabel independen, jika nilai VIF < 10000, maka dapat disimpulkan data bebas dari gejala multikolinieritas.

\subsection{Uji Heteroskedastisitas}

Uji Heteroskedastisitas adalah uji yang menilai apakah ada ketidaksamaan varian dari residual untuk semua pengamatan pada model regresi linear. Uji ini merupakan salah satu dari uji asumsi regresi klasik yang harus dilakukan pada regresi linear. Apabila asumsi heteroskedastisitas tidak terpenuhi, maka model regresi dinyatakan tidak valid sebagai alat peramalan.

Glejser test digunakan pada penelitian ini untuk menguji adanya gejala heteroskedastisitas pada model persamaan. Model tes ini umumnya memberikan hasil yang memuaskan dalam mendeteksi heteroskedastisitas. Oleh karena itu, Glejser test dapat digunakan untuk sampel yang besar dan dapat digunakan dalam sampel kecil secara ketat (Gujarati, 2004).

Gejala terjadinya heteroskedastisitas ditunjukkan dengan nilai probabilitas chi square pada obs*R-Square. Jika nilai probabilitas chi square lebih besar dari tingkat alpha 5\%, maka model persamaan yang digunakan dalam penelitian bersifat homoskedastisitas atau tidak ditemukan gejala heteroskedastisitas.

\section{HASIL DAN PEMBAHASAN}

\subsection{Gambaran Umum Ekspor Kakao dan Hilirisasi Kakao Indonesia}

Kakao menjadi salah satu komoditas andalan ekspor. Indonesia adalah produsen ketiga terbesar di dunia, tingkat produksinya dibawah Pantai Gading dan Ghana.

Produksi kakao pada tahun 2001 mencapai 536,8 ribu ton. Sedangkan total produksi kakao pada tahun 2017 mencapai 657,05 ribu ton. Secara keseluruhan total produksi kakao dari tahun 2001 sampai dengan 2017 mencapai 12,018 juta ton dan rataan per tahunnya sebesar 691,09 ribu ton.

Perkembangan produksi kakao sejak tahun 2001 mengalami keadaan yang fluktuatif. Berdasarkan Gambar 4., jumlah produksi kakao terbesar terjadi pada tahun 2010 dengan total produksi mencapai 837,9 ribu ton. Sedangkan jumlah produksi terendah terjadi pada tahun 2001 dengan total produksi sebesar 536,8 ribu ton. Peningkatan produksi terbesar terjadi pada tahun 2002-2003 dengan total kenaikan produksi sebesar $22,35 \%$ atau sekitar 127,6 ribu ton dari tahun sebelumnya. Sedangkan penurunan produksi terbesar terjadi pada 2014-2015 dengan tingkat penurunan produksi sebesar $22,76 \%$ atau 135,08 ribu ton dari tahun sebelumnya.

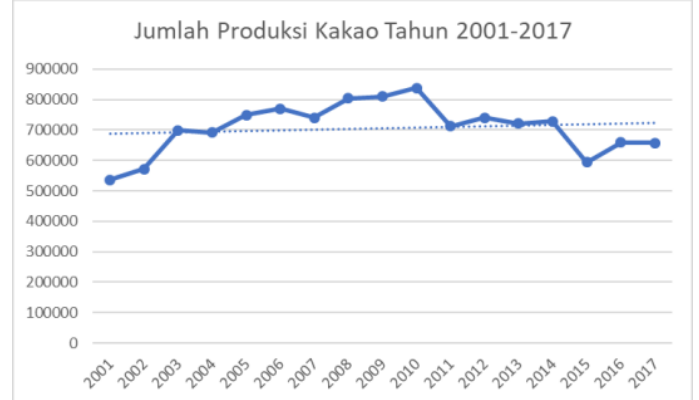

Gambar 4. Jumlah Produksi Kakao Indonesia

Sementara itu di sisi volume ekspor kakao di pasar internasional, dalam periode 2001-2017 cenderung mengalami penurunan. Volume ekspor kakao terbesar terjadi pada tahun 2006 dengan total sebesar 609,03 ribu ton.

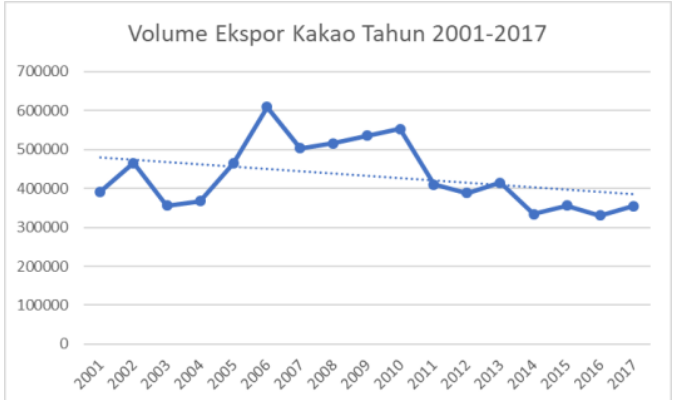

Gambar 5. Volume Ekspor Kakao Indonesia 
Ekspor kakao kemudian mengalami penurunan dan mencapai angka terendah pada tahun 2016 sebesar 330,03 ribu ton. Total volume ekspor sejak tahun 20012017 sebesar 734,61 ribu ton dengan rataan per tahun sebesar 431,68 ribu ton.

Ekspor kakao Indonesia terdiri atas 4 HS utama yaitu Kakao Butter (HS 1804000000), Tepung Kakao (HS 1805000000), Olahan makanan (HS 1806909000), dan Biji Kakao (HS $1803200000)^{4}$. Pada tahun 2017, menurut Badan Pusat Statistik, volume ekspor Kakao Butter sebesar $39 \%$ dari total ekspor, Tepung Kakao 23\%, Olahan makanan sebesar 19\%, dan Biji Kakao sebesar 7\%. Dengan demikian hasil olahan kakao mendominasi ekspor secara keseluruhan.

Penerapan bea keluar atas kakao adalah langkah awal program hilirisasi kakao Indonesia. Pemerintah mengeluarkan Peraturan Menteri Keuangan No. 67/PMK.011/2010 tentang Penetapan Barang Ekspor yang dikenakan Bea Keluar dan Tarif Bea Keluar. PMK ini menetapkan biji kakao sebagai komoditi yang dikenakan bea keluar secara progresif. Pemberlakuan peraturan ini sebagai bentuk menjamin ketersediaan kakao dalam negeri, sekaligus upaya untuk peningkatan hasil olahan kakao.

Pemberlakuan bea keluar atas ekspor kakao pada tahun 2010 membuat volume ekspor kakao mengalami penurunan dan relatif konstan. Pada Gambar 6., menggambarkan penurunan volume ekspor kakao sejak tahun 2010. Penurunan volume ekspor pada saat harga kakao dunia dan nilai tukar relatif konstan diikuti oleh perubahan nilai ekspor kakao.

Grafik ini mengimplikasikan bahwa terjadi perubahan ekspor kakao yang sebelum tahun 2010 mengandalkan komoditi biji kakao menjadi komoditas olahan. Sebelum 2010 keadaan volume ekspor dan nilai ekspor bergerak beriringan, hal ini mengindikasikan nilai ekspor dipengaruhi oleh satu komoditi saja. Setelah Tahun 2010 nilai ekspor tidak mengikuti grafik volume ekspor yang relatif konstan. Hal ini, mengimplikasikan adanya perbedaan variasi komoditi yang diekspor sehingga nilainya berubah bergantung pada permintaan pasar. Sehingga kebijakan bea keluar membantu percepatan hilirisasi kakao Indonesia.

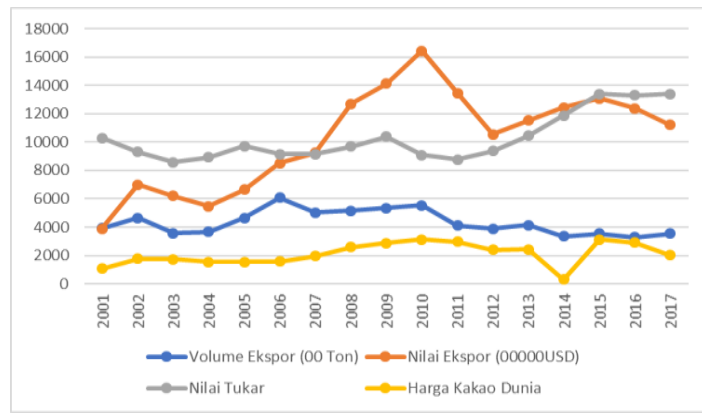

Gambar 6. Perbandingan Volume Ekspor, Nilai Ekspor, Harga Kakao Dunia, Nilai Tukar Rupiah di Indonesia

Pergeseran ekspor kakao dari barang mentah menjadi barang jadi atau setengah jadi merupakan salah satu tujuan dari program hilirisasi kakao Indonesia. Menurut Kementerian Perindustrian, hilirisasi kakao menjadi prioritas dalam Rencana Induk Pembangunan Industri Nasional (RIPIN) 2915-2035 ditetapkan dengan Peraturan Pemerintah No. 14 tahun 2015. Adapun cara yang dilakukan adalah pembaharuan peraturan tentang harga patokan ekspor dan tarif bea keluar secara teratur, pembuatan unit pengolahan di sentra produksi kakao, pendirian program Cocoa Sustainability Partnership, bantuan peralatan industri, Rancangan Standar Nasional Coklat Indonesia dan teaching industry pada Pusat Pengembangan Kompetensi Industri Pengolahan Kakao Terpadu (PPKIPKT).

${ }^{4}$ Menggunakan BTKI Tahun 2012 


\subsection{Hasil Analisis Regresi}

Untuk mengetahui dampak kebijakan bea keluar terhadap ekspor kakao di pasar dunia, terlebih dahulu dilakukan pengujian model regresi OLS. Analisis pendahuluan yang dilakukan terhadap regresi dengan data time series dalam penelitian ini adalah uji stasioneritas. Analisis ini digunakan untuk memastikan hasil regresi OLS tidak menghasilkan spurious correlation maka variabel dalam penelitian ini diuji dengan Augmented Dickey Fuller (ADF).

Tabel 1.

Augmented Dickey Fuller Test

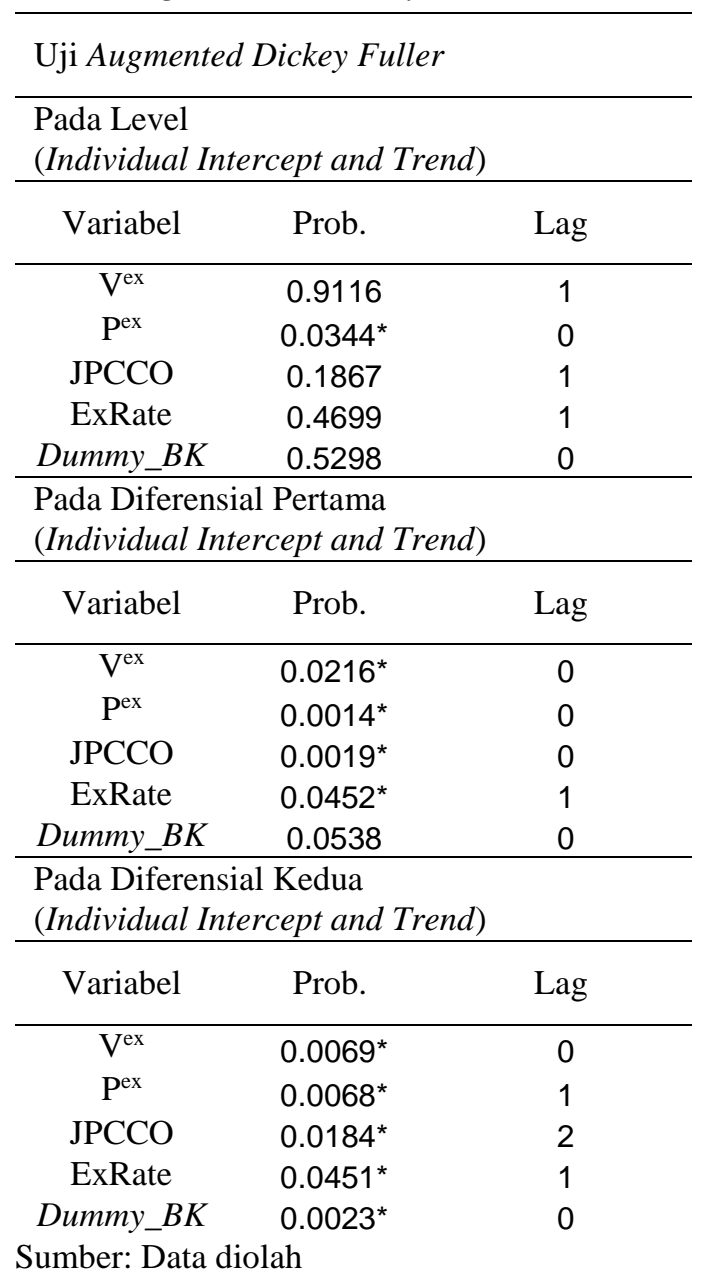

Hasil uji ADF menunjukkan variabel dependen maupun independen pada tingkatan level hanya variabel harga kakao dunia $\left(\mathrm{P}^{\mathrm{ex}}\right)$ yang stasioner $(0.0344<0.05)$. Untuk variabel lain dalam persamaan menunjukkan gejala kointegrasi atau tidak stasioner, ditunjukkan dari nilai probabilitas lebih besar dari tingkat critical value alpha 5\% (Prob. > 0.05). Pada tingkatan diferensial orde pertama dengan asumsi individual intercept and trend variabel kebijakan bea keluar (Dummy_BK) dinyatakan tidak stasioner, nilai probabilitasnya lebih besar dibanding tingkat alpha $5 \% \quad(0.0538>0.05)$. Selanjutnya pada tingkatan diferensial orde kedua, keseluruhan variabel yang digunakan dalam model persamaan penelitian ini memiliki nilai probabilitas lebih kecil dibanding tingkat alpha 5\%. Keseluruhan variabel stasioner dan tidak terjadi gejala kointegrasi. Sehingga hasil analisis dapat memiliki long term correlation antara variabelnya.

Uji Normalitas dilakukan dengan metode Jarque-Bera. Keputusan data dinyatakan berdistribusi normal dilakukan membandingkan nilai Probabilitas JB (Jarque-Bera) hitung dengan tingkat alpha $5 \%$. Data yang digunakan dalam penelitian ini berdasarkan hasil estimasi pada tabel 2, menunjukkan residual berdistribusi normal. Nilai probabilitas hitung sebesar 0.592427 lebih besar dari 0,05 maka dapat disimpulkan bahwa residual berdistribusi normal.

Tabel 2.

Jarque-Bera Test

Uji Normalitas Jarque-Bera

\begin{tabular}{ll}
\hline Jarque-Bera & 1.047054 \\
Probability & 0.592427 \\
\hline Sumber: Data diolah &
\end{tabular}

Hasil estimasi autokorelasi terhadap variabel dalam penelitian ini dilakukan dengan Breusch-Godfrey Serial Correlation LM Test. Pada tabel 3, Obs*RSquared bernilai 1.467847 dengan probabilitas chi-squared sebesar 0.4800 . Sedangkan penentuan terjadinya gejala autokorelasi ditunjukkan oleh probabilitas F $(2,11)$ atau $F$ hitung pada F-statistik. 
Nilai probabilitas $\mathrm{F}$ hitung lebih besar dibanding tingkat alpha 0,05 (0.6367 > $0.05)$ berdasarkan hasil estimasi tersebut tidak terjadi autokorelasi. Data yang digunakan dalam penelitian ini tidak dipengaruhi oleh data tahun sebelumnya dan nilai disturbance berpasangan secara bebas.

Tabel 3.

Autocorrelation Test

Breusch-Godfrey Serial Correlation LM Test

\begin{tabular}{cccc}
\hline $\begin{array}{c}\text { F- } \\
\text { statistic }\end{array}$ & 0.472519 & $\begin{array}{c}\text { Prob. F } \\
(2,11)\end{array}$ & 0.6367 \\
$\begin{array}{c}\text { Obs*R- } \\
\text { Squared }\end{array}$ & 1.467847 & $\begin{array}{c}\text { Prob. Chi- } \\
\text { Squared } \\
(2)\end{array}$ & 0.4800 \\
& & & \\
\hline
\end{tabular}

Sumber: Data diolah

Uji multikolinieritas selanjutnya dilakukan untuk menunjukkan ada atau tidaknya interkorelasi dalam persamaan penelitian ini. Interkorelasi berdampak pada koefisien parsial regresi yang tidak dapat diukur secara presisi akibat standar error yang besar. Terjadinya gejala multikolinieritas juga menyebabkan variabel dalam penelitian berkorelasi kuat dengan variabel lainnya, maka hasil analisis tidak stabil.

Tabel 4.

VIF Test

\begin{tabular}{ccc}
\hline Variable & $\begin{array}{c}\text { Coefficient } \\
\text { Variance }\end{array}$ & $\begin{array}{c}\text { Centered } \\
\text { VIF }\end{array}$ \\
\hline C & 72.90893 & NA \\
JPCCO & 0.206242 & 1.229324 \\
Pex $^{\text {ExRate }}$ & 0.008307 & 1.050919 \\
Dummy_BK & 0.186660 & 1.702785 \\
\hline
\end{tabular}

Sumber: Data diolah

Pada Tabel 4, nilai Variance Inflation Factor (VIF) seluruh variabel di bawah ambang batas toleransi sebesar 10000 . Dengan demikian, tidak terjadi multikolinieritas antara variabel-variabel yang digunakan dalam persamaan pada penelitian ini. Model persamaan dalam penelitian dapat memprediksi dengan handal.

Uji asumsi terakhir yang dilakukan pada penelitian ini adalah uji heteroskedastisitas. Uji dilakukan dengan metode pengujian Glejser. Hasil estimasi akan menunjukkan adanya varian error yang konstan atau tidak. Berdasarkan hasil estimasi pada Tabel 5, gejala heteroskedastisitas ditentukan melalui perbandingan nilai probabilitas $\mathrm{F}$ hitung dengan tingkat alpha. Nilai probabilitas $\mathrm{F}$ hitung sebesar 0.5480 lebih besar dibanding 0.05 , maka tidak terjadi gejala heteroskedastisitas dan dinyatakan homoskedastisitas.

Tabel 5

Glejser Test

\begin{tabular}{|c|c|c|c|}
\hline \multicolumn{4}{|c|}{ Heteroskedasticity Test: Glejser } \\
\hline $\begin{array}{c}\text { F- } \\
\text { statistic }\end{array}$ & 0.799993 & $\begin{array}{l}\text { Prob. F } \\
(4,13)\end{array}$ & 0.5480 \\
\hline $\begin{array}{l}\text { Obs*R- } \\
\text { Squared }\end{array}$ & 3.578921 & $\begin{array}{l}\text { Prob. Chi- } \\
\text { Squared (4) }\end{array}$ & 0.4660 \\
\hline $\begin{array}{c}\text { Scaled } \\
\text { Explaine } \\
\text { d SS }\end{array}$ & 1.359813 & $\begin{array}{l}\text { Prob. Chi- } \\
\text { Squared (4) }\end{array}$ & 0.8511 \\
\hline
\end{tabular}

Sumber: Data diolah

Hasil regresi OLS pada Tabel 6, menunjukkan keseluruhan variabel memiliki koefisien yang positif. Analisis regresi menghasilkan persamaan:

$\ln \mathrm{V}^{\mathrm{ex}}=-21.798+1.9531 \ln \mathrm{JPCCO}+$ $0.1684 \ln \mathrm{P}^{\mathrm{ex}}+0.8512 \ln$ Exrate +0.3375 Dummy_BK+ $\mathrm{e}_{1}$

keterangan $=$ nilai koefisien dibulatkan keatas. 
Tabel 6.

Hasil Regresi

\begin{tabular}{cccc}
\hline Variable & Coefficient & t-Statistic & Prob. \\
\hline C & -21.79880 & -2.552950 & 0.0253 \\
JPCCO & 1.953097 & 4.300666 & 0.0010 \\
P $^{\text {ex }}$ & 0.168406 & 1.847744 & 0.0894 \\
ExRate & 0.851188 & 1.970154 & 0.0723 \\
Dummy_ & 0.337482 & 2.804113 & 0.0159 \\
BK & & & \\
\hline R-squared & & 0.804860 & \\
Adjusted R-squared & 0.739813 & \\
F-Statistic & 12.37358 & \\
\hline Prob(F-Statistic) & 0.000322 & \\
\hline Sumber: Data diolah &
\end{tabular}

Hasil regresi pengaruh variabel secara parsial maupun simultan. Secara keseluruhan variabel atau faktor yang digunakan berpengaruh secara simultan terhadap variabel ekspor kakao. Hasil uji menghasilkan $\mathrm{F}$ hitung sebesar 12.3735 sedangkan nilai $\mathrm{F}$ tabel sebesar 3.26 (dengan $\mathrm{k}=5$ dan $\mathrm{n}=17$ ). Nilai $\mathrm{F}$ hitung $>\mathrm{F}$ tabel $(13.3735>3.26)$ dan nilai Probabilitas F lebih kecil dibanding tingkat alpha $5 \%(0.0003<0.05)$, maka dapat disimpulkan bahwa variabel jumlah produksi kakao, harga kakao, nilai tukar rupiah, dan kebijakan bea keluar secara simultan berpengaruh signifikan terhadap ekspor kakao. Nilai F hitung > F tabel (13.3735 > 3.26) juga berarti bahwa model persamaan penelitian ini dinyatakan Good of Fit.

Variabel jumlah produksi kakao menunjukkan pengaruh positif yang signifikan. Nilai probabilitas variabel jumlah produksi lebih kecil dibanding tingkat alpha 5\%. Koefisien sebesar 1.953 menunjukkan bahwa kenaikan jumlah produksi kakao sebesar 1 satuan akan meningkatkan ekspor kakao sebesar 1.953 satuan, dengan asumsi ceteris paribus.

Hasil estimasi ini sesuai dengan penelitian Maulana et al (2017), yang menunjukkan jumlah produksi kakao berpengaruh signifikan terhadap ekspor kakao Indonesia ke negara tujuan ekspor kakao utama. Jumlah produksi kakao mempengaruhi secara langsung ekspor kakao Indonesia, hal ini dikarenakan sebagian besar produksi kakao diperuntukkan untuk pasar internasional. Produksi kakao tersebar di 7 sentra utama penghasil kakao dan diekspor ke beberapa negara, sisanya akan dikirim ke beberapa wilayah dalam negeri untuk kemudian diolah menjadi produk kakao lokal. Peningkatan hasil produksi mendorong kinerja ekspor kakao dan meningkatkan daya saing di pasar internasional.

Pengujian terhadap variabel harga kakao dunia dan nilai tukar rupiah terhadap dolar menunjukkan pengaruh positif dan secara parsial tidak signifikan terhadap ekspor kakao. Hasil estimasi variabel harga kakao dunia ini sejalan dengan penelitian Mejaya et al (2016). Sedangkan hasil estimasi terhadap variabel nilai tukar rupiah sesuai dengan penelitian Puspita et al (2015). Pengaruh signifikan terhadap kedua variabel terjadi pada keadaan approached conventional of significance $e^{5}$ yang dalam penelitian ini tidak digunakan.

Harga kakao dunia dengan probabilitas 0.0894 lebih besar dari tingkat alpha yang ditentukan dalam penelitian ini sebesar 5\%. Variabel nilai tukar juga menunjukan nilai probabilitas yang lebih tinggi dari tingkat alpha yang ditentukan.

Kedua variabel ini erat kaitannya dengan hukum permintaan. Menurut Mankiw (2012), jumlah permintaan barang menurun ketika harga naik dan meningkat ketika harga turun. Hal ini berarti jumlah permintaan barang berbanding terbalik dengan harga. Jika hal-hal lain tetap, ketika harga suatu barang naik jumlah permintaan untuk barang tersebut akan turun dan sebaliknya.

${ }^{5}$ Probabilitas lebih kecil dibanding tingkat Alpha $10 \%$ 
Menurut teori, seharusnya setiap kenaikan nilai tukar akan menurunkan harga dan biaya dari suatu barang bagi negara pengimpor (tujuan ekspor). Penurunan harga ini menyebabkan harga barang semakin murah di negara pengimpor, dan negara pengekspor mendapatkan profit yang lebih tinggi karena melakukan transaksi melalui valuta asing.

Untuk ekspor kakao Indonesia kedua variabel ini tidak mempengaruhi secara signifikan. Struktur industri menghasilkan barang ekspor didominasi dengan bahan baku supply dari barang-barang yang akan diimpor, sehingga setiap kenaikan nilai tukar justru akan meningkatkan daya beli bahan baku dan membuat biaya produksi menjadi semakin murah sehingga meningkatkan ekspor.

Trend kenaikan ekspor Indonesia lebih didorong oleh kekuatan daya saing kakao di market place internasional dibanding kenaikan harga-harga komoditas di pasar Internasional. Tinggi atau rendahnya harga kakao di pasar internasional tetap akan terjadi permintaan karena kakao yang diekspor oleh 3 negara eksportir kakao terbesar merupakan bahan baku untuk produk lainnya. Sehingga naik ataupun turunnya ekspor kakao dipengaruhi oleh kualitas kakao yang diekspor dan kemampuan bersaing dengan negara eksportir lainnya dalam keadaan harga yang sama.

Variabel kebijakan bea keluar memiliki pengaruh positif dan signifikan terhadap ekspor kakao Indonesia pada taraf 5\%. Nilai probabilitas lebih kecil dibanding tingkat alpha sebesar 0.05 . Koefisien variabel kebijakan bea keluar sebesar 0.3374 menunjukkan kebijakan bea keluar meningkatkan nilai ekspor kakao sebesar 0.3374 dalam asumsi keadaan ceteris paribus. Hal ini sesuai dengan penelitian Suryana et al
(2014) dan Maulana et al (2017). yang menyatakan kebijakan bea keluar berpengaruh positif signifikan terhadap ekspor kakao indonesia. Yudyanto dan Fithra (2017), pengenaan pajak ekspor (bea keluar) pada biji kakao Indonesia secara signifikan mempengaruhi peningkatan nilai ekspor kakao Indonesia dalam jangka panjang. Pengaruh positif dan signifikan menunjukkan bahwa kebijakan bea keluar yang dimulai pada tahun 2010 memberikan dampak positif terhadap kinerja ekspor kakao indonesia.

Penerapan kebijakan bea keluar pada dasarnya dilakukan untuk meningkatkan daya saing produk kakao hasil olahan di pasar internasional. Sehingga Penerapan kebijakan bea keluar hanya diperuntukkan untuk menghambat ekspor kakao dalam bentuk biji kakao. Biji kakao yang tidak diekspor akibat adanya bea keluar kemudian diolah dan dimanfaatkan oleh industri pengolahan dalam negeri, hasil pengolahan tersebut kemudian diekspor atau digunakan untuk kebutuhan dalam negeri. Peningkatan ekspor kakao pasca kebijakan bea keluar adalah hasil dari ekspor kakao dalam bentuk olahan.

Menurut Syadullah (2012), Pasca penerapan kebijakan bea keluar biji kakao, jumlah perusahaan industri cacao processing terus mengalami peningkatan ${ }^{6}$. Fenomena beroperasinya kembali perusahaan dibidang cacao processing menunjukkan bahwa penerapan kebijakan bea keluar biji kakao berdampak positif terhadap upaya pengembangan industri hilir pengolahan kakao di dalam negeri. Selain mendorong beroperasinya kembali industri pengolahan kakao di dalam negeri, penerapan bea keluar biji kakao juga telah mendorong sejumlah investor asing untuk berinvestasi di Indonesia.

Secara keseluruhan model persamaan dalam penelitian ini menunjukkan nilai Adjusted R-Squared sebesar 0.7398.

${ }^{6}$ Media Industri. (2010). Penerapan Bea Keluar: Dorong Industri Hilir Kakao Domestik. Nomor 2, 2010. 
Sehingga keseluruhan variabel dependen yang digunakan berkontribusi sebesar $73.98 \%$. Sedangkan, $26.02 \%$ variabel lainnya tidak dibahas dalam penelitian ini.

\section{KESIMPULAN}

Berdasarkan hasil penelitian dapat disimpulkan bahwa secara keseluruhan variabel jumlah produksi, harga kakao dunia, nilai tukar rupiah dan kebijakan bea keluar berpengaruh secara simultan terhadap variabel ekspor kakao Indonesia dalam rentan tahun 2001-2017.

Variabel jumlah produksi dan kebijakan bea keluar secara parsial berpengaruh signifikan positif terhadap ekspor kakao Indonesia. Sedangkan variabel harga kakao dunia dan nilai tukar rupiah tidak berpengaruh signifikan terhadap ekspor kakao Indonesia pada tingkat alpha 5\%.

Pemberlakuan bea keluar atas ekspor kakao pada tahun 2010 membuat volume ekspor kakao mengalami penurunan dan relatif konstan. Sebelum tahun 2010 ekspor mengandalkan komoditi biji kakao. Kemudian setelah kebijakan bea keluar, ekspor kakao bergeser dari barang mentah menjadi barang jadi atau setengah jadi merupakan salah satu tujuan dari program hilirisasi kakao Indonesia.

Berdasarkan hasil penelitian di atas, kebijakan bea keluar terhadap ekspor biji kakao sebaiknya dipertahankan karena berdampak positif terhadap hilirisasi kakao Indonesia. Tarif bea keluar yang dikenakan secara seragam terhadap seluruh jenis biji kakao. Selain untuk kepentingan hilirisasi, kebijakan bea keluar juga diperlukan untuk pengendalian terhadap ketersediaan kakao untuk penggunaan dalam negeri.

\section{DAFTAR PUSTAKA}

Badan Pusat Statistik. (2018). Statistik Kakao Indonesia 2017. Diakses 4 Maret 2019, dari bps.go.id
Direktorat Jenderal Perkebunan. (2016). Statistik Perkebunanan Indonesia Kakao 2015-2017. Diakses 5 Maret 2019, dari ditjenbun.pertanian.go.id

Djalal, Nachrowi, dan Hardius Usman. (2006). Pendekatan populer dan praktis ekonometrika untuk analisis ekonomi dan keuangan. Jakarta: Lembaga Penerbit Fakultas Ekonomi Universitas Indonesia

Gujarati, Damodar N. (2004). Basic Econometrics Fourth Edition. New York: McGraw-Hill

Ghozali, Imam. (2011). Aplikasi Analisis Multivariate Dengan Program IBM SPSS

Harsanti, Ari, Bambang Juanda, dan Sahara. (2014). Dampak Bea Keluar Kakao Indonesia Terhadap Country Marker Power di Pasar Biji Kakao Amerika Serikat Dan Terms of Trade. Jurnal Agribisnis Indonesia Volume. 2 No. 2, 107-126

Helpman, E. dan P. R. Krugman. (1989). Trade Policy and Market Structure. Cambridge, Massachusetts: The MIT Press

Putri, Afrianingsih, Osmet, dan Rusda Khairati. (2014). Pengaruh Kebijakan Pajak Ekspor (Bea Keluar) Terhadap Variabel-variabel Perdagangan Biji Kakao Indonesia. Jurnal Agribisnis Kerakyatan, 4, 59-64

Kementerian Perindustrian. (2007). Gambaran Sekilas Industri Kakao. Diakses 8 Maret 2019, dari kemenperin.go.id

Kuncoro, Mudrajad. (2003). Metode Riset untuk Bisnis \& Ekonomi. Jakarta: Erlangga

Luhur, Estu Sri dan Tajerin. (2016). Dampak Pemberlakuan Bea Keluar Terhadap Kinerja Ekspor Sektor Kelautan dan Perikanan Indonesia. Jurnal Sosek KP Volume 11 No. 2.2016, hal 185-200

Mankiw. (2003). Teori Makroekonomi. Edisi ke-5. Erlangga. Jakarta 
Mankiw, N. Gregory, Euston Quah, Peter Wilson. (2012). Principles of Economics an Asian Edition Volume 1. Jakarta: Penerbit Salemba Empat

Maulana, Arif dan Fitri Kartiasih. (2017). Analisis Ekspor Kakao Olahan Indonesia ke Sembilan Negara Tujuan Tahun 2000-2014. Jurnal Ekonomi dan Pembangunan Indonesia Volume. 17 No. 2, 103-117

Mejaya, Amirus Saleh, Dahlan Fanani, M. Kholid Mawardi. (2016). Pengaruh Produksi, Harga Internasional, dan Nilai Tukar Terhadap Volume Ekspor. Jurnal Administrasi Bisnis Volume. 35 No. 2, 20-29

Munadi, E. (2007). Penurunan Pajak Ekspor dan Dampaknya Terhadap Ekspor Minyak Kelapa Sawit Indonesia ke India (Pendekatan Error Correction Model). Informatika Pertanian Volume 16 No. 2, 2007, 1019-1036

Puspita, Ratna, Kadarisman Hidayat, Edy Yulianto. (2015). Pengaruh Produksi Kakao Domestik, Harga Kakao Internasional, dan Nilai Tukar Terhadap Ekspor Kakao Indonesia ke Amerika Serikat. Jurnal Administrasi Bisnis Volume. 27 No. 1, 1-8

Salvatore, Dominick. (1997). Ekonomi Internasional. Terjemahan oleh Haris Munandar Edisi Kelima Jilid 1. Jakarta: Erlangga

Santoso, Singgih. (2010). Statistik Parametrik, Konsep, dan Aplikasi dengan SPSS. Jakarta: Elex Media Komputindo

Sugiono. (2011). Metode Penelitian Pendidikan (Pendekatan, Kuantitatif, Kualitatif, dan R\&D). Bandung: Alfabeta

Sujarweni, V. Wiratna. (2015). Metode Penelitian Bisnis \& Ekonomi. Yogyakarta: Pustaka Baru Press
Suliyanto. (2011). Ekonometrika Terapan: Teori \& Aplikasi dengan SPSS. Yogyakarta: ANDI

Supranto, J. (2008). Statistik Teori dan Aplikasi. Jakarta: Erlangga

Suryana, Anggita T, Anna Fariyanti, dan Amzul Rifin. (2014). Analisis Perdagangan Kakao Indonesia di Pasar Internasional. Jurnal Tanaman Industri dan Penyegar Volume. 1 No.1, 29-40

Syadullah, Makmun. (2012). Dampak Kebijakan Bea Keluar Terhadap Ekspor dan Industri Pengolahan Kakao. Buletin Ilmiah Litbang Perdagangan Volume. 6 No.1 (2014). Dampak Bea Keluar Terhadap Ekspor CPO Indonesia. Kajian Ekonomi Keuangan Volume. 18 No. 3, 241-254

Yudyanto, Hendy, Fithra Faisal H. (2017). Analysisi of the Imposisition $O F$ Export Tax on Indonesian Cocoa Beans: Impact on the Processed Cocoa Export Indonesia and Malaysia. International Journal of Economics and Financial Issues Vol. 7 No. 5, 552-560

\section{Peraturan Perundang-undangan}

Republik Indonesia, Undang-Undang Nomor 17 Tahun 2006 j.o UndangUndang Nomor 10 Tahun 1995 Tentang Kepabeanan

Kementerian Keuangan Republik Indonesia, Peraturan Menteri Keuangan Nomor 67/PMK.011/2010 Tentang Penetapan Barang Ekspor yang Dikenakan Bea Keluar dan Tarif Bea Keluar Peraturan Menteri Keuangan Nomor 13/PMK.010/2017 Tentang Penetapan Barang Ekspor yang Dikenakan Bea Keluar dan Tarif Bea Keluar 